\title{
Influence of the carbon source on nisin production in Lactococcus lactis subsp. lactis batch fermentations
}

\author{
LUC DE VuYST* and ERICK J. VANDAMME
}

\begin{abstract}
Laboratory of General and Industrial Microbiology, Faculty of Agricultural Sciences, University of Gent, Coupure links 653, B-9000 Gent, Belgium
\end{abstract}

(Received 30 May 1991; revised 5 September 1991; accepted 6 November 1991)

\begin{abstract}
Nisin production by Lactococcus lactis subsp. lactis NIZO 22186 was studied in batch fermentation using a complex medium. Nisin production showed primary metabolite kinetics: nisin biosynthesis took place during the active growth phase and completely stopped when cells entered the stationary phase. A stringent correlation could be observed between the expression of the prenisin gene (nisA) and the synthesis of the post-translationally enzymically modified and processed mature nisin peptide. Moreover, it seemed likely that nisin had a growth control function. A physiological link is proposed between sucrose fermentation capacity and nisin production ability. Carbon source regulation appears to be a major control mechanism for nisin production.
\end{abstract}

\section{Introduction}

Lactic acid bacteria produce a wide variety of antagonistic factors that include metabolic end-products such as lactic acid, antibiotic-like substances and antimicrobial proteins or bacteriocins (Klaenhammer, 1988; Lindgren $\&$ Dobrogosz, 1990). The antimicrobial activities of the industrially important lactic acid bacteria have long been known and traditionally applied, and these play an important role in food fermentations, food preservation and intestinal ecology (Gilliland, 1986, 1990). Among the antimicrobial proteins produced by lactic acid bacteria, nisin is the most studied (Hurst, 1981; Rayman \& Hurst, 1984; Liu \& Hansen, 1990).

The bioactive peptide nisin is synthesized by certain strains of Lactococcus lactis subsp. lactis (De Vuyst et al., 1990) and is active against Gram-positive bacteria (Hurst, 1981). It has a molecular mass of $3500 \mathrm{Da}$ and is composed of 34 amino acids, including three 2,3-unsaturated amino acid residues, one dehydroalanine and two 3-methyldehydroalanines or didehydrobutyrines, five thioether amino acids, one lanthionine and four 3-methyllanthionines (Gross \& Morell, 1971). Nisin is therefore a pentacyclic lantibiotic (Kaletta \& Entian, 1989). The lantibiotics are a group of peptide antibiotics, containing 19-34 amino acids, which are characterized

* Author for correspondence. Tel. (91) 646027; fax (91) 646245.

Abbreviation: CDW, cell dry weight. by the occurrence of these thioether amino acids. They are produced from a ribosomally synthesized precursor peptide, which is subsequently post-translationally enzymically modified (Kellner et al., 1988). The unusual amino acids should be responsible for the functionally important properties of the nisin molecule, i.e. thermostability and bactericidal action. Today, nisin is commercially produced exclusively by microbial fermentation (Vandamme, 1984) and is used in processed cheese and canned foods. However, it has many other potential applications as a biological food preservative (Hurst, 1981; Rayman \& Hurst, 1984).

Information about the microbial production of the lantibiotics in batch fermentations is scarce (Sahl \& Brandis, 1981; Kido et al., 1983; Hörner et al., 1989, 1990). Nisin batch fermentations have already been described (e.g. Hirsch, 1951; Hurst, 1966; Oberman \& Jacubowska, 1968; Egorov et al., 1971; Kozlova et al., 1972; Lee \& Kim, 1985) but so far there has been no systematic examination of nutritional parameters in relation to growth kinetics and lantibiotic metabolism in producing strains. The present study was undertaken to increase understanding of the physiology and metabolic control of nisin biosynthesis. Several attempts to increase nisin yields by genetic manipulation have been tried but were unsuccessful (Gasson, 1984; Tsai \& Sandine, 1987). A better understanding of the nisin biosynthetic process and of its metabolic regulation seems to be a prerequisite for achieving improved nisin yields. 


\section{Methods}

Bacterial strains and media. The nisin-producing strain used in this study was Lactococcus lactis subsp. lactis NIZO 22186. It was stored at $4{ }^{\circ} \mathrm{C}$ in liquid yeast dextrose litmus milk (YDLM) medium consisting of $\left(\mathrm{g}^{-1}\right)$ : litmus milk (Oxoid), 100.0; yeast extract (Oxoid), 3.0; glucose, $10 \cdot 0$. The $\mathrm{pH}$ was adjusted to $6 \cdot 80$ before a threefold tyndallization at $100^{\circ} \mathrm{C}$ for $30 \mathrm{~min}$. A complex medium (CM-medium) was used for nisin production. It contained the following ingredients $\left(1^{-1}\right)$ : sucrose, $10.0 \mathrm{~g}$; peptone (Oxoid), $10.0 \mathrm{~g}$; yeast extract (Oxoid), 10.0 g; $\mathrm{KH}_{2} \mathrm{PO}_{4}, 10.0 \mathrm{~g} ; \mathrm{NaCl}, 2.0 \mathrm{~g} ; \mathrm{MgSO}_{4} \cdot 7 \mathrm{H}_{2} \mathrm{O}, 0.2 \mathrm{~g}$. To prepare the inoculum, a similar medium was used which lacked peptone. In this publication, this modified medium will be referred to as inoculation medium. The initial $\mathrm{pH}$ of both media was adjusted to 6.80 ; the media were then autoclaved at $121^{\circ} \mathrm{C}$ for $20 \mathrm{~min}$.

Fermentation. L. lactis subsp. lactis NIZO 22186 precultures were grown for $5 \mathrm{~h}$ at $30^{\circ} \mathrm{C}$ in $9 \mathrm{ml}$ inoculation medium and subcultured for $10 \mathrm{~h}$ at $30^{\circ} \mathrm{C}$ in $70 \mathrm{ml}$ inoculation medium. A fresh culture of actively growing cells was always used as the inoculum; the inoculum size was always $1 \%(\mathrm{v} / \mathrm{v})$. Fermentations were run in Erlenmeyer flasks $(500 \mathrm{ml})$ containing $300 \mathrm{ml}$ production medium and in a 6.21 fermenter (New Brunswick Bioflo II) filled with 51 of medium to ensure microaerophilic conditions. The Erlenmeyer flasks were incubated at $30^{\circ} \mathrm{C}$ without agitation. The fermenter was operated at $30^{\circ} \mathrm{C}$ without aeration; slow agitation ( 50 r.p.m.) was continuously provided to keep the fermentation broth homogeneous. The $\mathrm{pH}$ was measured (uncontrolled $\mathrm{pH}$ fermentations) or controlled continuously by automatic addition of $10 \mathrm{M}-\mathrm{NaOH}$. Samples were withdrawn at regular intervals, and analysed for growth, nisin activity and residual sucrose concentration.

Growth determination. Growth was measured as optical density (OD) at $600 \mathrm{~nm}$ or by cell dry weight (CDW) determinations. The centrifuged cells $(10000 \mathrm{~g}, 10 \mathrm{~min})$ were washed twice with saline $(0.85 \% \mathrm{NaCl})$.

Nisin activity determination. For estimating nisin activity, $1 \mathrm{ml}$ samples were diluted with $9 \mathrm{ml} \mathrm{0.02} \mathrm{M}-\mathrm{HCl}$. The tubes were then placed in a boiling-water bath for $5 \mathrm{~min}$ and then centrifuged $(5000 \mathrm{~g}$ ) for $10 \mathrm{~min}$. The nisin activity of medium supernatant was determined by bioassay, which was performed by a quantitative agar diffusion method using $M$. flavus DSM 1790 (which is sensitive to nisin) (Tramer \& Fowler, 1964). A standard curve (1-10 IU ml-1) was plotted using a stock solution of $1000 \mathrm{IU}$ nisin $\mathrm{ml}^{-1}$. The latter was prepared by dissolving $100 \mathrm{mg}$ of Nisaplin (Aplin \& Barrett Ltd., Trowbridge, Wiltshire, UK) into $90 \mathrm{ml} 0.02 \mathrm{M}-\mathrm{HCl}$ and $10 \mathrm{ml}$ of the sterile fermentation medium used. Samples were diluted with $0.02 \mathrm{M}-\mathrm{HCl}$. Each assay was performed in triplicate.

Sucrose concentration determination. Residual sucrose levels were determined enzymically using a Boehringer kit for sucrose determinations (Cat. No. 139041, Boehringer Mannheim).

RNA isolation and Northern blot analysis. L. lactis was incubated in M17 medium (Terzaghi \& Sandine, 1975) supplemented with $5 \mathrm{~g}$ sucrose $1^{-1}$ as a carbon source, at $30^{\circ} \mathrm{C}$ without aeration until an $\mathrm{OD}_{600}$ of 0.8 was achieved. Cells were collected by centrifugation and resuspended in THMS buffer (30 mM-Tris, $3 \mathrm{mM}-\mathrm{MgCl}_{2}$ in $25 \%$ (w/v) sucrose, $\mathrm{pH} \mathrm{8.0)}$ and subsequently digested with $50 \mu \mathrm{g}$ lysozyme $\mathrm{ml}^{-1}$ (Sigma) for $30-45 \mathrm{~min}$ at $37^{\circ} \mathrm{C}$. After centrifugation, the mixture was resuspended in 0.1 vols buffer I (0.5 M-sucrose, $20 \mathrm{mM}$-sodium acetate, $1 \mathrm{mM}$-EDTA, pH 5.5). Subsequently, 0.4 vols buffer II (20 mM-sodium acetate, $1 \mathrm{mM}$-EDTA, $0.5 \%$ SDS, pH 5.5) and 0.5 vols acid phenol (pH 5.5) were added, with occasional mixing. After incubation at $60^{\circ} \mathrm{C}$ for $5 \mathrm{~min}$, the water phase was separated and repeatedly extracted with acid phenol. The RNA was finally ethanol-precipitated. RNA fractionation was performed on a denaturing formaldehyde gel, blotted onto a Gene Screen Plus nylon membrane (NEN, Du Pont) and hybridized. Hybridization was performed overnight at $42{ }^{\circ} \mathrm{C}$ with a natural prenisin structural gene - the L. lactis subsp. lactis NIZO R5 nis $A$ gene - as a DNA probe, which had first been radioactively labelled by nick-translation. The blot was washed at $42^{\circ} \mathrm{C}$ in $2 \times \mathrm{SSC}$ $(1 \times \mathrm{SSC}$ is $0.15 \mathrm{M}-\mathrm{NaCl}$ plus $0.015 \mathrm{M}$-sodium citrate) supplemented with $0 \cdot 1 \%$ SDS and subsequently developed by autoradiography at $-80^{\circ} \mathrm{C}$.

Protein analysis. Proteins were analysed by Tricine-SDS-PAGE (Schagger \& von Jagow, 1987), and silver-stained using BioRad reagents.

\section{Results and Discussion}

\section{Dynamics of nisin formation in batch fermentations}

\section{Uncontrolled pH fermentations}

The nisin production kinetics of Lactococcus lactis subsp. lactis NIZO 22186 were examined in the sucrose-based complex medium described. A batch fermentation profile of microbial growth and nisin production at uncontrolled $\mathrm{pH}$ is presented in Fig. 1. Exponential growth took place during a period of about $4-5 \mathrm{~h}$ at a maximum specific growth rate of $0.66 \mathrm{~h}^{-1}$. Maximum cell density was reached after $8 \mathrm{~h}$ and amounted to $1.27 \mathrm{~g}$ CDW per litre of medium. Nisin production appeared to parallel that of biomass. Bactericidal nisin activity was already detectable after $4 \mathrm{~h}$ of growth. When about $60 \%$ of the biomass had been formed, there was a strong increase in nisin production. The highest nisin titre was reached at the end of the exponential phase, and corresponded with maximal biomass. Consequently, nisin was produced in the active growth phase. Nisin production completely stopped when cells entered the stationary phase. All these characteristics of nisin production clearly differentiate it from that of authentic secondary metabolites (Kleinkauf et al., 1986; Martin \& Liras, 1989). Almost all bacteriocins produced by lactic acid bacteria are produced during the active growth phase; further, the lantibiotics Pep 5 (Sahl \& Brandis, 1981), ancovenin (Kido et al., 1983), epidermin (Hörner et al., 1989) and gallidermin (Hörner et al., 1990) are also synthesized during the growth phase of the producer strain.

Despite rapid biomass formation and nisin production early in the culture, final high biomass and nisin levels could not be obtained, primarily because of an early sharp decrease in $\mathrm{pH}$, owing to lactic acid accumulation. In the fermentation process with $10 \mathrm{~g}$ sucrose $\mathrm{l}^{-1}$ as carbon source, the low $\mathrm{pH}$ presumably had an adverse effect on growth when about $60 \%$ of the sucrose had been converted to lactic acid. Moreover, during fermentations with increasing initial sucrose concentrations up to 


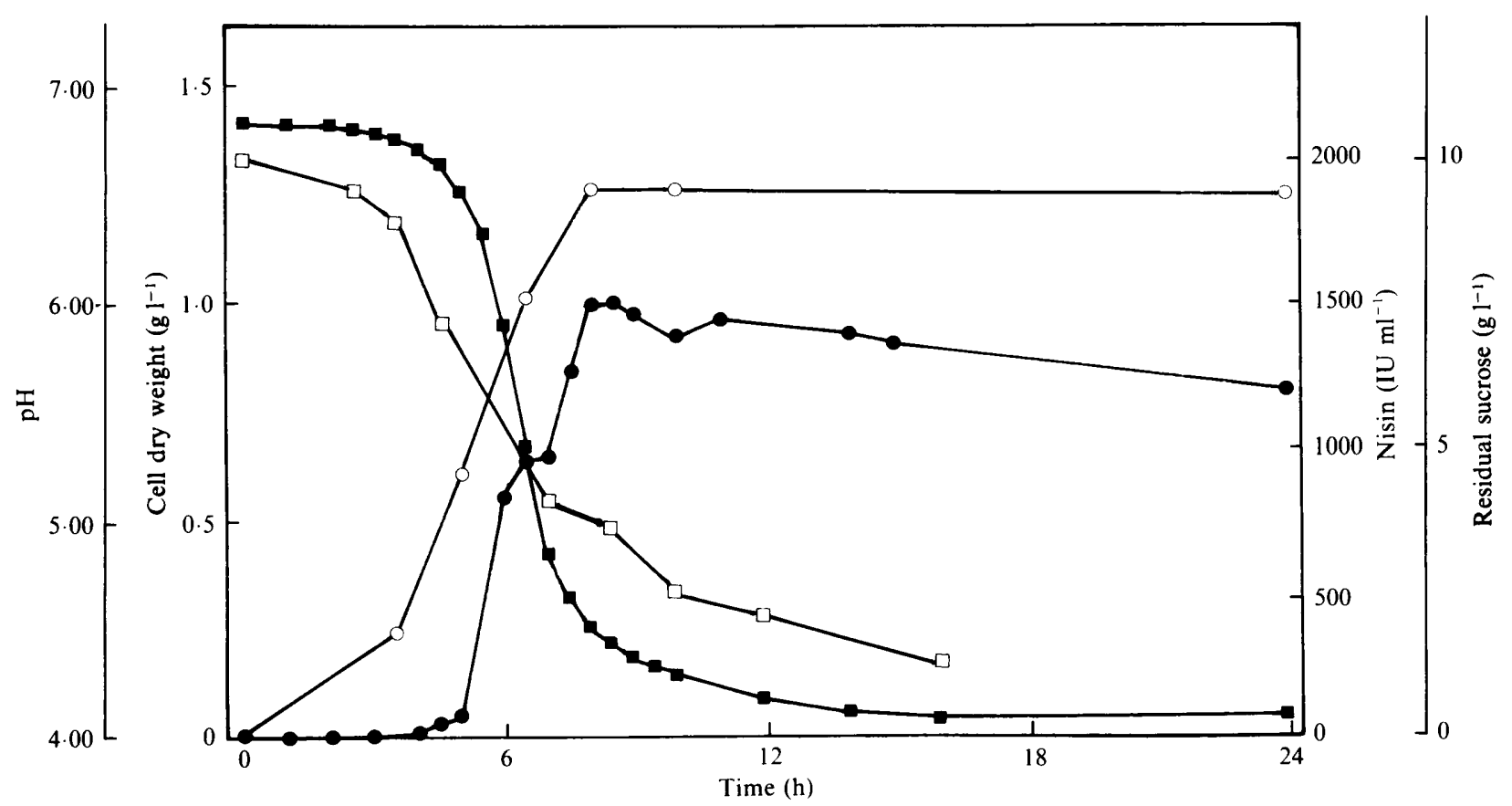

Fig. 1. Batch fermentation profile of Lactococcus lactis subsp. lactis NIZO 22186 microbial growth and nisin production at uncontrolled $\mathrm{pH}$. Cells were grown in a fermenter containing 51 nisin production medium with $10 \mathrm{~g}$ sucrose $\mathrm{l}^{-1}$ as carbon source (see Methods). Cell dry weight $\left(\mathrm{g} \mathrm{l}^{-1}\right), 0$; volumetric nisin titre $\left(\mathrm{IU} \mathrm{ml}^{-1}\right), \bullet$; residual sucrose concentration $\left(\mathrm{g}^{-1}\right), \square ; \mathrm{pH}, \boldsymbol{\square}$.

$30 \mathrm{~g}^{-1}$, no more than $7 \cdot 1 \mathrm{~g}$ sucrose $1^{-1}$ could be consumed. Even by increasing the initial sucrose concentration to $100 \mathrm{~g} \mathrm{l}^{-1}$, using Erlenmeyer flasks containing $300 \mathrm{ml}$ production medium, maximum biomass averaged only about $0.85 \mathrm{~g}$ CDW per litre of medium, and the maximum nisin titre was approximately $2000 \mathrm{IU}$ nisin $\mathrm{ml}^{-1}$ irrespective of the addition of surplus sucrose. The maximal specific nisin production reached values of approximately $54 \mathrm{mg}$ nisin $(\mathrm{g} \mathrm{CDW})^{-1}$ [calculated for a pure nisin preparation with a specific activity of $40 \times 10^{6} \mathrm{IU}\left(\mathrm{g}\right.$ nisin) $\left.{ }^{-1}\right]$.

The effect of $\mathrm{pH}$ on the growth of lactic acid bacteria is well known (Gilliland, 1986), but $\mathrm{pH}$ regulation of nisin biosynthesis must also be considered. $\mathrm{pH}$ regulation of the biosynthesis of antibiotics is not exceptional. For example, a $\mathrm{pH}$-limiting effect was observed in Bacillus brevis gramicidin S production byVandamme (1981), and Hörner et al. $(1989,1990)$ optimized epidermin and gallidermin production after an initial acidification of the culture medium.

\section{Controlled $p H$ fermentations}

Fig. 2 represents the nisin batch fermentation profile under nutritional conditions as above, with $10 \mathrm{~g}$ sucrose $1^{-1}$ as a carbon source, but controlling the $\mathrm{pH}$ at $6 \cdot 80$. Neutralization of lactic acid by continuous addition of $10 \mathrm{M}-\mathrm{NaOH}$ increased the final biomass yield as well as the nisin titre. With $10 \mathrm{~g}$ sucrose $\mathrm{I}^{-1}$ as a carbon substrate, $2.34 \mathrm{~g}$ CDW per litre of medium could be obtained. However, growth had already ceased after $8 \mathrm{~h}$ of fermentation, mainly because no sucrose was left. The nisin titre increased almost proportionally with growth and reached its maximum, i.e. $1793 \mathrm{IU}$ nisin (ml medium $)^{-1}$, at the end of the exponential growth phase, again corresponding with maximal biomass. The corresponding maximum specific nisin production was about $19 \mathrm{mg}$ nisin $(\mathrm{g} \mathrm{CDW})^{-1}$. After reaching their peak values, both the nisin and biomass levels dropped sharply. The high production rate of nisin during the microbial growth phase suggests that a continuous fermentation process could be considered for nisin production.

\section{Expression of the prenisin gene (nis A)}

Fermentation profiles indicated that nisin production shows primary metabolite kinetics. However, nisin production increased rapidly at the end of the exponential growth phase. To explain the observed nisin fermentation profile in detail, expression of the nisin precursor gene was studied by Northern blot analysis. $L$. lactis was therefore grown in M17 medium, supplemented with $5 \mathrm{~g}$ sucrose $\mathrm{I}^{-1}$ as a carbon source. Growth was followed by measuring the $\mathrm{OD}_{600}$. Samples were removed at different stages of growth (correspond- 


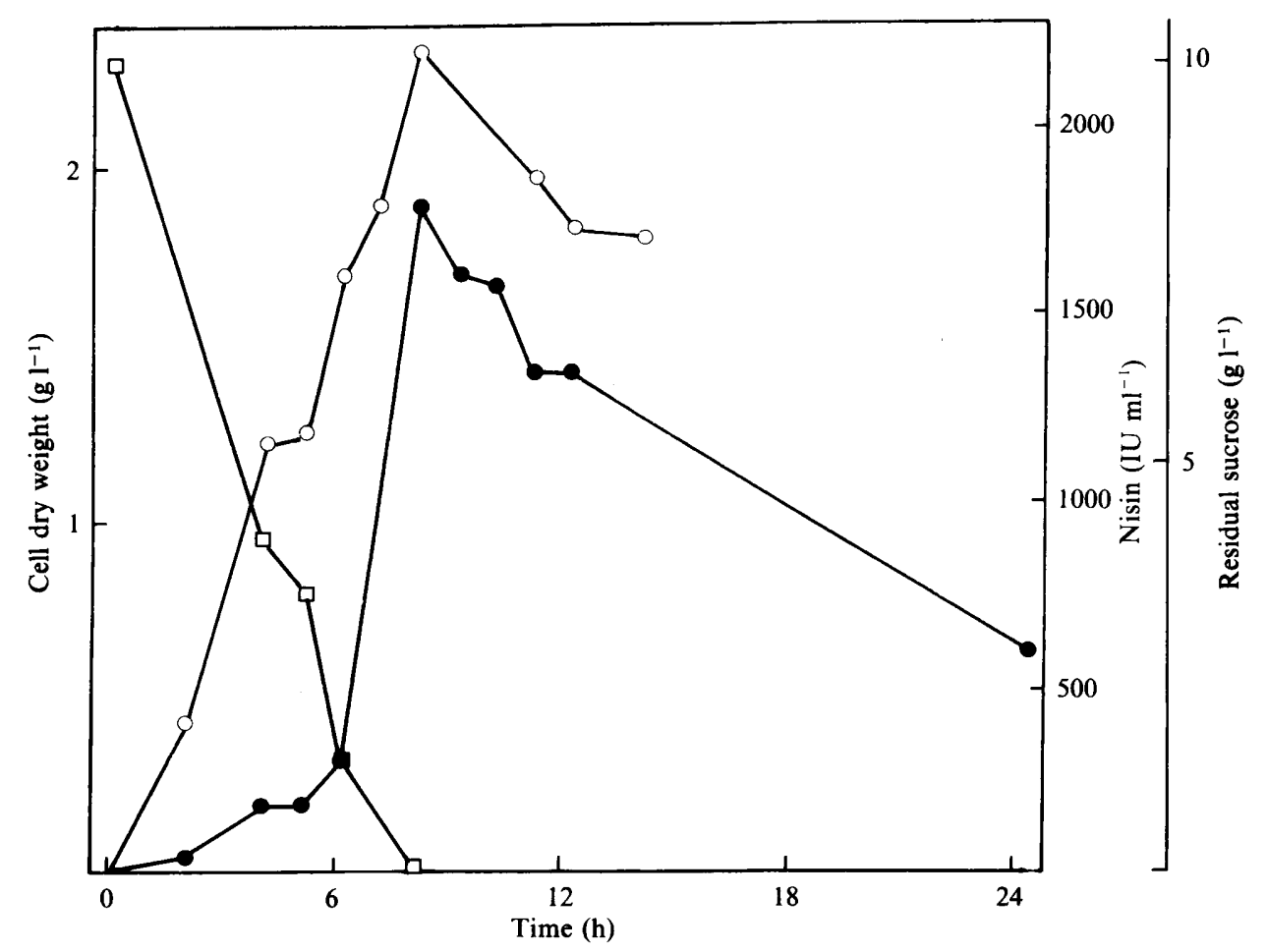

Fig. 2. Batch fermentation profile of Lactococcus lactis subsp. lactis NIZO 22186 microbial growth and nisin production at controlled pH 6-80. Cells were grown in a fermenter containing 51 nisin production medium with $10 \mathrm{~g}$ sucrose $\mathrm{l}^{-1}$ as carbon source (see Methods).

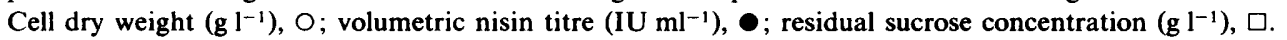

ing to optical densities of $0.25,0.50,0.75$ and 1.00$)$ and centrifuged. The supernatant fluids were first assayed for nisin bioactivity and afterwards were lyophilized, TCAprecipitated and electrophoresed. The gel was silverstained for protein, to reveal any nisin present. From the pelleted cells, total RNA was isolated, electrophoresed and blotted for Northern analysis, in which the labelled natural prenisin structural gene was used as a probe. These results are presented in Fig. 3. The growth curve shows that nisin activity could be detected early in the exponential growth phase, where a peptide band with a size of $3.5 \mathrm{kDa}$ (corresponding to that of mature nisin) could also be seen. Because of the requirement for posttranslational enzymic modification and processing of the nisin precursor, the prenisin gene would have to be transcribed before this event. Indeed, the Northern analysis revealed a hybridizing band with an apparent size of about 350 nucleotides that was already present in cells harvested in the early exponential growth phase, as well as in cells derived from the mid-exponential and late-exponential growth phases. Consequently, transcription of the structural nisin precursor gene and synthesis of prenisin had already started in the early exponential growth phase and continued until the stationary phase. Moreover, throughout the fermentation process, a good correlation existed between the synthesis of this prenisin-mRNA (as revealed by Northern analysis), the occurrence of a mature nisin peptide band (as shown by the Tricine-SDS-PAGE) and the detection of nisin bioactivity in the fermentation broth (tested by bioassay). Such a well defined correlation exists, for instance, for the lantibiotic subtilin only in the stationary growth phase, where an increased induction of presubtilin-mRNA occurs (Banerjee \& Hansen, 1988). These data indicate that the later increase in nisin bioactivity as compared to cellular growth can not be explained by a delayed expression of the nisin precursor gene, but would rather depend on the expression of the appropriate prenisin modifying or nisin generating enzymes.

\section{Prolonged fermentations - functional role of nisin}

After reaching peak values, the nisin levels and biomass decreased rapidly with a prolonged fermentation time, particularly in pH-controlled fermentations. Similar fermentation patterns were obtained for several other lactic acid bacteria bacteriocins, for instance lacticin DP1 production by L. lactis subsp. lactis (Piard et al., 1988) and sakacin A production by Lactobacillus sake LB 706 (Schillinger \& Lücke, 1989). The concentrations of other lantibiotics such as Pep 5 (Sahl \& Brandis, 1981), 

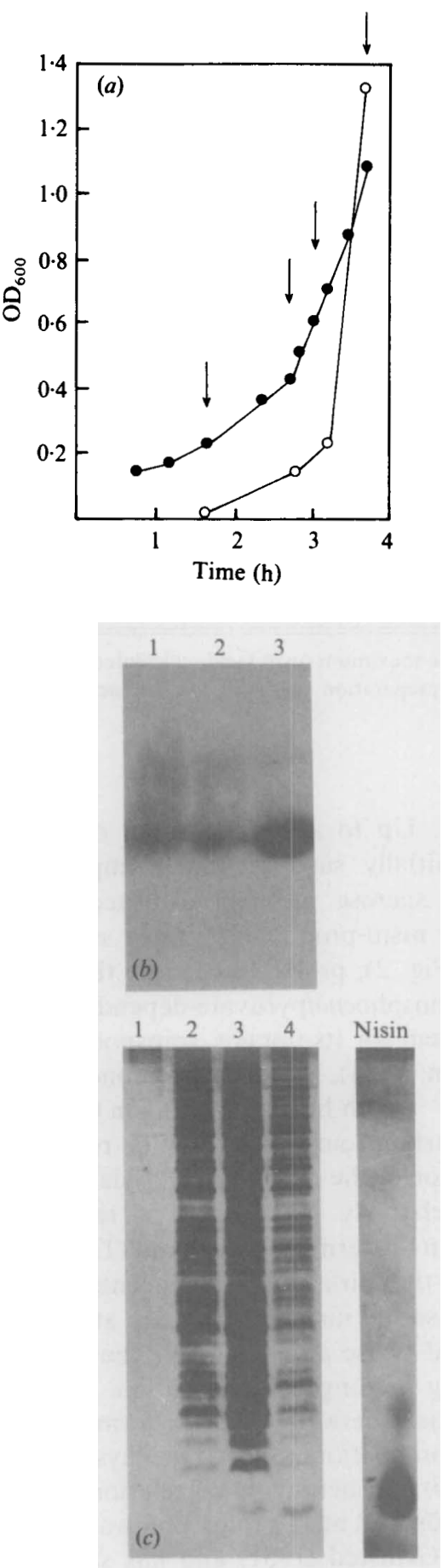

Fig. 3. Northern blot analysis of RNA isolated from different growth stages of Lactococcus lactis subsp. lactis NIZO 22186. (a) Growth (•) and nisin production $(\mathrm{O})$ kinetics during batch fermentation at

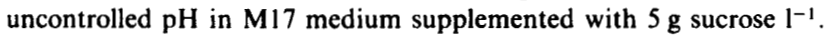
Growth was followed by measuring the $\mathrm{OD}_{600}$. Cell-free culture supernatants were assayed for nisin bioactivity. Arrows indicate times at which samples were withdrawn for Northern blot and protein analysis. (b) Northern blot of RNA isolated from different growth stages. The time indications (1), (2) and (3) correspond to the arrows in (a). The blot was hybridized to the radioactively labelled natural ancovenin (Kido et al., 1983), epidermin (Hörner et al., 1989) and gallidermin (Hörner et al., 1990) have been shown to decrease as soon as the maximal antibiotic titres were reached. The decrease of the nisin titre after $8 \mathrm{~h}$ of fermentation implies that the fermentation process would need to be stopped by then to achieve a maximum specific nisin productivity.

Several hypotheses can be formulated to explain the sudden decrease of the biomass levels during nisin batch fermentation: an external bacteriophage attack during fermentation; induced lysis of a possible lysogenic producer strain by unknown factors; high intracellular accumulation of nisin and autolysis of the cells due to the exhaustion of the carbon source.

Kozak et al. (1973) reported that a high intracellular antibiotic concentration could also induce cell lysis. However, L. lactis subsp. lactis NIZO 22186 was immune to nisin up to an extracellular concentration of $10000 \mathrm{IU}$ pure nisin (ml medium $)^{-1}$. Moreover, no intracellular nisin could be detected via Tricine-SDS-PAGE (unpublished data). Indeed, the mature active peptide should be secreted into the medium after processing (Kellner et al., 1988). The fact that cell lysis always occurred at the same moment during different fermentations and the usual observation of the culture showing increased viscosity, are a possible indication of lysogeny. Also, UV irradiation of exponentially growing cells of the nisin producer strain L. lactis subsp. lactis NIZO 22186 induced lysis (data not shown). Indeed, most nisin producers seem to be lysogenic (Kozak et al., 1973). Lysogeny together with the fact that several nisin producing L. lactis subsp. lactis strains possess a rather low proteinase activity (De Vuyst et al., 1990), make it difficult to use these strains as starter cultures in cheese production on a large scale. However, a controlled cell lysis would be advantageous during cheese ripening because of the release of different peptidases and lipases.

Another possible explanation for the decrease in nisin titre is the release of non-specific proteolytic enzymes during cell lysis. Increased proteinase activity was observed towards the end of the fermentation cycle (data not shown) and the excretion of proteases during the stationary phase is common for dairy fermentations (Law, 1980; Law \& Kolstad, 1983) and during fermentation of several other oligopeptide antibiotics. Continuous on-line adsorption of nisin onto an appropriate adsorber material during the fermentation process or the use of a membrane reactor could overcome proteolytic degradation. This has been experimentally and success-

prenisin structural gene (nisA) of L. lactis subsp. lactis NIZO R5. (c) Silver-stained protein profile of total protein in the supernatant fluids from samples removed at different times during growth, corresponding to arrows in (a). A band of $3.5 \mathrm{kDa}$, corresponding to the molecular mass of nisin, was present at all times nisin bioactivity was observed. 
fully applied for epidermin and gallidermin (Hörner $e t$ al., 1989, 1990).

It is also possible that the mature nisin peptide might have been destroyed by a nisinase, a specific nisindestroying enzyme. Nisinases have already been isolated from Streptococcus salivarius subsp. thermophilus, Lactobacillus plantarum and Bacillus cereus (Rayman \& Hurst, 1984). Buchman et al. (1988) discovered an ORF upstream of the structural prenisin gene in the bacterial genome of the nisin producer L. lactis subsp. lactis ATCC 11454 that might be a candidate gene for a nisinase. However, it remains unclear why a nisin producer strain would produce a nisinase. This enzyme might be responsible for the high immunity of the producer strain against its own product. However, all these observations point to a possible regulatory function of nisin in the growth cycle of the nisin producing micro-organism, as postulated by Hurst (1978), although not all L. lactis subsp. lactis strains produce nisin. Whether other biologically inactive basic peptides in nisin non-producing L. lactis subsp. lactis strains (Hurst \& Paterson, 1971), might have a similar growth control function to that suggested for producer strains, and what the actual role of the antibiotic activity would then be, remain unknown.

\section{Effect of sucrose levels}

Since nisin titre invariably seems to be proportionally related to biomass yield, especially under $\mathrm{pH}$-controlled conditions, achieving a high biomass may be a prerequisite for high nisin production. Consequently, to improve the antibiotic yield further by generating higher cell densities, higher concentrations of the carbon source were tested in fermentations run at a controlled $\mathrm{pH}$ of $6 \cdot 80$. Using an initial concentration of sucrose of $20 \mathrm{~g} \mathrm{l}^{-1}$, the maximum biomass level was increased 1.5 times as compared with a fermentation with an initial sucrose concentration of $10 \mathrm{~g} \mathrm{t}^{-1}$. However, it did not prolong the active growth phase, and only increased the nisin activity by about $20 \%$. A large increase in nisin production occurred only in the late exponential phase (Fig. 2). Higher concentrations of sucrose (greater than $20 \mathrm{~g} \mathrm{l}^{-1}$ ) yielded a higher biomass, but did not increase the nisin activity concomitantly (Table 1). The cell production amounted to $7.47 \mathrm{~g} \mathrm{CDW}^{-1}$, whereas nisin production peaked at only $3267 \mathrm{IU}$ nisin (ml medium $)^{-1}$, both at a level of $40 \mathrm{~g}$ sucrose $1^{-1}$. Because of this non-linear relationship between biomass yield and nisin production level, sucrose at $10 \mathrm{~g} \mathrm{l}^{-1}$ provided the highest specific nisin productivity [approximately $19 \mathrm{mg}$ nisin $\left.(\mathrm{g} \mathrm{CDW})^{-1}\right]$. However, for high nisin yields, high specific nisin production is not sufficient. A critical amount of biomass seems to be a very important
Table 1. Influence of initial sucrose concentration on Lactococcus lactis subsp. lactis NIZO 22186 growth and nisin production in fermentations at controlled pH $6 \cdot 80$

Fermentations were run in a fermenter containing 51 nisin production medium (see Methods). Samples were withdrawn at regular intervals. Results are maximum values obtained during fermentation.

\begin{tabular}{|c|c|c|c|c|c|}
\hline \multirow{2}{*}{$\begin{array}{l}\text { Initial } \\
\text { sucrose } \\
\left(\mathrm{g}^{-1}\right)\end{array}$} & \multirow{2}{*}{$\begin{array}{c}\text { Cell } \\
\text { dry weight } \\
\text { (CDW) } \\
\left(\mathrm{g}^{-1}\right)\end{array}$} & \multicolumn{2}{|c|}{$\begin{array}{c}\text { Volumetric } \\
\text { nisin activity } \\
{[\text { IU nisin }} \\
\left.\text { (ml medium })^{-1}\right]\end{array}$} & \multirow{2}{*}{$\begin{array}{c}Y_{\mathrm{p} / \mathrm{x}}^{*} \\
{\left[\mathrm{mg} \mathrm{nisin}^{\left.\mathrm{g} \mathrm{CDW})^{-1}\right]}\right.}\end{array}$} & \multirow{2}{*}{$\begin{array}{c}\text { Residual } \\
\text { sucrose } \\
\left(\mathrm{g} \mathrm{l}^{-1}\right)\end{array}$} \\
\hline & & Maximum & After $24 \mathrm{~h}$ & & \\
\hline $10 \cdot 0$ & $2 \cdot 34$ & 1793 & 617 & $19 \cdot 1$ & 0.0 \\
\hline $20 \cdot 0$ & 3.40 & 2184 & 1620 & $16 \cdot 0$ & 0.0 \\
\hline $30 \cdot 0$ & 4.53 & 2936 & 2286 & $16 \cdot 2$ & $1 \cdot 2$ \\
\hline $40 \cdot 0$ & 7.47 & 3267 & 2671 & $10 \cdot 9$ & 0.2 \\
\hline $50 \cdot 0$ & 5.79 & 2937 & 2714 & $12 \cdot 7$ & $2 \cdot 8$ \\
\hline $70 \cdot 0$ & $4 \cdot 74$ & 1596 & 1300 & $8 \cdot 4$ & 18.7 \\
\hline
\end{tabular}

${ }^{*} Y_{\mathrm{p}, \mathrm{s}}$ is the maximum nisin yield, calculated per gram CDW for a pure nisin preparation with a specific activity of $40 \times 10^{6} \mathrm{IU}$ $(\mathrm{g} \text { nisin })^{-1}$.

parameter. Up to a concentration of $40 \mathrm{~g} \mathrm{l}^{-1}$, all the sucrose initially supplied was completely consumed. Moreover, sucrose, although a disaccharide, is rapidly utilized by nisin-producing $L$. lactis subsp. lactis strains (see also Fig. 2), probably because they possess a very efficient phosphoenolpyruvate-dependent phosphotransferase system for its uptake, transport and metabolism (Thompson, 1988). With sucrose concentrations higher than $40 \mathrm{~g} \mathrm{l}^{-1}$, both biomass and nisin titres decreased. A limiting carbon source could not be responsible for this phenomenon or the observed cell lysis mentioned above, because relatively high levels of residual sugar still remained in the fermentation broth (Table 1). Generally, the higher the initial sucrose concentration, the greater the increase in nisin production at the end of the exponential phase and the lower the decrease in nisin titre during prolonged fermentation. Finally, a genetic linkage exists between sucrose fermentation capacity and nisin production ability (De Vuyst, 1990; De Vuyst et al., 1990). A phenotypic correlation between sucrose fermentation and nisin production was first observed by Hirsch \& Grinsted (1951) and has since been studied genetically by several investigators (Kozak et al., 1974; Fuchs et al. 1975; Leblanc et al., 1980; Gasson, 1984; Gonzalez \& Kunka, 1985; Steele \& McKay, 1986). In most cases, the sucrose and nisin genes were localized to a large plasmid, the so called sucrose-nisin-plasmid or pSN-plasmid. These conclusions were supported by successful curing and conjugation experiments. However, conflicting results have been obtained which suggest that nisin production is mediated by either 
chromosomal or plasmid DNA (Davey \& Pearce, 1982; Fuchs et al., 1985). More recently, it has been shown that the structural genes for the nisin precursor (Buchman et al., 1988; De Vuyst, 1990; Dodd et al., 1990) and sucrose6-P-hydrolase (P. J. M. Rauch \& W. M. de Vos, unpublished results) are chromosomally encoded. Moreover, genes involved in nisin biosynthesis (Steen et al., 1991) and sucrose fermentation (P. J. M. Rauch \& W. M. de Vos, unpublished results) could form an operon, localized on a conjugative transposon of about $70 \mathrm{~kb}$ (Gasson, 1990). In any case, a genetic regulatory system or a common metabolic control system may be responsible for the linkage between sucrose fermentation capacity and nisin biosynthesis ability.

All the above results suggest carbon source regulation of nisin biosynthesis. Firstly a genetic regulatory system or a common metabolic control system for sucrose fermentation and nisin production capacity and dynamics may be responsible for the observed linkage between those metabolic traits. Secondly, because the small protein antibiotic nisin is synthesized via a chromosomally encoded precursor protein consisting of 57 amino acids (Buchman et al., 1988; Dodd et al., 1990), this precursor-nisin must be post-translationally modified by one or more enzymes (Kaletta \& Entian, 1989). These modifications include dehydration of serines and threonines to double bond dehydroforms which then react with neighbouring cysteines to give lanthionine and 3-methyllanthionine (Ingram, 1970). Because Northern blot analysis revealed that the prenisin structural gene (nis $A$ ) is expressed early in the exponential growth phase, the large increase of nisin production towards the end of the active growth phase (see also Figs 1 and 2) could be the result of non-optimal nutritional control of microbial growth and subsequent delayed enzyme formation. According to the fermentation profiles of Figs 1 and 2, it seems possible that the formation of these prenisin-modifying enzymes or nisin-generating enzymes is carbon-source-regulated. These enzymes could be repressed during the early exponential growth phase and become derepressed later on. Hurst \& Paterson (1971) had already postulated a maximal specific enzyme activity in the late exponential phase. After reaching their peak specific activities, the enzymes would rapidly disappear as the cells entered stationary growth phase. Consequently, derepression or activation of the processing enzymes by optimal nutritional and metabolic regulation could be responsible for higher nisin activity levels earlier in growth.

Nisin production clearly shows primary metabolite kinetics. According to the fermentation profiles presented here, it seems likely that nisin, or its precursor, has a growth control function. On the other hand, some results indicate that nisin production is regulated by the carbon source. Expresson of the prenisin structural gene occurs in the early exponential growth phase. Increased nisin production rate towards the end of the active growth phase could be due to delayed formation of the necessary prenisin-modifying enzymes. Whether the regulation is either genetically or enzymically mediated, and whether the processing enzymes are controlled by carbon catabolite repression, inhibition or inactivation is not yet known. Future investigations will be directed to the molecular mechanism of nisin biosynthesis, to the time-course of appearance and disappearance of the nisin-generating enzymes during batch fermentation, and to their regulation by different carbon sources.

Luc De Vuyst is a senior research assistant of the Belgian National Fund for Scientific Research (NFWO). The authors are grateful to the NFWO for financial support of this project and thank the Netherlands Institute for Dairy Research (NIZO, Ede, The Netherlands), especially Prof. Dr W. de Vos, Dr J. Mulders and P. Rauch, for their help in the RNA isolations.

\section{References}

Banerjee, S. \& Hansen, J. N. (1988). Structure and expression of a gene encoding the precursor of subtilin, a small protein antibiotic. Journal of Biological Chemistry 263, 9508-9514.

Buchman, G. W., Banerjee, S. \& Hansen, H. N. (1988). Structure, expression, and evolution of a gene encoding the precursor of nisin, a small protein antibiotic. Journal of Biological Chemistry 263, $16260-16266$.

Davey, G. P. \& Pearce, L. E. (1982). Production of diplococcin by Streptococcus cremoris and its transfer to nonproducing group $\mathbf{N}$ streptococci. In Microbiology - 1982, pp. 221-224. Edited by D. Schlessinger. Washington, DC: American Society for Microbiology.

DE VUYST, L. (1990). Biosynthesis, fermentation and genetics of the Lactococcus lactis subsp. lactis lantibiotic, nisin. Ph.D. Thesis, State University of Gent.

De Vuyst, L., Mulders, J., de Vos, W. M. \& Vandamme, E. J. (1990). Phenotypic and genotypic characterization of nisin-producing Lactococcus lactis subsp. lactis strains. In Abstract Book of the 6th International Symposium on Genetics of Industrial Microorganisms, Strasbourg, August 12-18, 1990, p. 186, D-62.

DodD, H. M., HoRN, N. \& Gasson, M. J. (1990). Analysis of the genetic determinant for production of the peptide antibiotic nisin. Journal of General Microbiology 136, 555-566.

Egorov, N. S., Baranova, I. P. \& Kozlova, YU. I. (1971). Optimization of nutrient medium composition for the production of the antibiotic nisin by Streptococcus lactis. Mikrobiologiya 40 , 993-998.

Fuchs, P. G., Zajdel, J. \& Dobrzanski, W. T. (1975). Possible plasmid nature of the determinant for production of the antibiotic nisin in some strains of Streptococcus lactis. Journal of General Microbiology 88, 189-192.

Gasson, M. J. (1984). Transfer of sucrose fermenting ability, nisin resistance and nisin production into Streptococcus lactis 71. FEMS Microbiology Letters 21, 7-10.

Gasson, M. J. (1990). In vivo genetic systems in lactic acid bacteria. FEMS Microbiology Reviews 87, 43-60.

Gilliland, S. E. (1986). Bacterial Starter Cultures for Foods. Boca Raton, Florida: CRC Press.

Gilliland, S. E. (1990). Health and nutritional benefits from lactic acid bacteria. FEMS Microbiology Reviews 87, 175-188.

Gonzalez, C. F. \& KunKa, B. S. (1985). Transfer of sucrose fermenting ability and nisin production phenotype among lactic streptococci. Applied and Environmental Microbiology 49, 627-633. 
Gross, E. \& MORELL, J. (1971). The structure of nisin. Journal of the American Chemical Society 93, 4634-4635.

HiRSCH, A. (1951). Growth and nisin production of a strain of Streptococcus lactis. Journal of General Microbiology 5, 208-221.

HiRSCH, A. \& GRINSTED, E. (1951). The differentiation of the lactic streptococci and their antibodies. Journal of Dairy Research 18, 198-204.

Horner, T., ZahNer, H., Kellner, R. \& JUNG, G. (1989). Fermentation and isolation of epidermin, a lanthionine containing polypeptide antibiotic from Staphylococcus epidermidis. Applied Microbiology and Biotechnology 30, 219-225.

Horner, T., UngermanN, V., Zahner, H., Fiedler, H.-P., UtZ, R., Kellner, R. \& JUNG, G. (1990). Comparative studies on the fermentative production of lantibiotics by staphylococci. Applied Microbiology and Biotechnology 32, 511-517.

HURST, A. (1966). Biosynthesis of the antibiotic nisin by whole Streptococcus lactis organisms. Journal of General Microbiology 44, 209-220.

HURST, A. (1978). Nisin: its preservative effect and function in the growth cycle of the producer organism. In Streptococci, pp. 297-314. Edited by F. A. Skinner \& L. B. Quesnel. London : Academic Press.

Hurst, A. (1981). Nisin. Advances in Applied Microbiology 27, 85-123.

Hurst, A. \& PATERson, G. M. (1971). Observations on the conversion of an inactive precursor protein to the antibiotic nisin. Canadian Journal of Microbiology 17, 1379-1384.

INGRAM, A. (1970). A ribosomal mechanism for synthesis of peptides related to nisin. Biochimica et Biophysica Acta 224, 263-265.

KaletTA, C. \& ENTIAN, K.-D. (1989). Nisin, a peptide antibiotic: cloning and sequencing of the nis $A$ gene and post-translational processing of its peptide product. Journal of Bacteriology 171, $1597-1601$.

Kellner, R., Jung, G., Horner, T., Zahner, H., Schnell, N., ENTIAN, K.-D. \& GoTZ, F. (1988). Gallidermin, a new lanthionine containing polypeptide antibiotic. European Journal of Biochemistry $177,53-59$.

Kido, Y., Hamakado, T., Yoshida, T., Anno, M., Motoki, Y., WAKamiYa, T. \& SHIBA, T. (1983). Isolation and characterization of ancovenin, a new inhibitor of angiotensin I converting enzyme, produced by actinomycetes. Journal of Antibiotics 36, 1295-1299.

KLAENHAMmer, T. R. (1988). Bacteriocins of lactic acid bacteria Biochimie 70, 337-349.

Kleinkauf, H., von Dohren, H., Dornauer, H. \& Nesemann, G. (1986). Regulation of Secondary Metabolite Formation. Weinheim $\mathrm{VCH}$.

Kozak, W., Rajchert-TrZPIL, M., Zajdel, J. \& Dobrzanski, W. T. (1973). Lysogeny in lactic streptococci producing and not producing nisin. Applied Microbiology 25, 305-308.

Kozak, W., Rajchert-TrzPIL, M. \& DobrzanSKI, W. T. (1974). The effect of proflavin, ethidium bromide and an elevated temperature on the appearance of nisin-negative clones in nisin-producing strains of Streptococcus lactis. Journal of General Microbiology 83, 295302.

Kozlova, Yu. I., Egorov, N. S., Baranova, I. P. \& Maksimov, V. N. (1972). Metabolic kinetics of Streptococcus lactis on initial and optimal media. Mikrobiologiya 41, 1007-1012.

LAw, B. A. (1980). Transport and utilization of proteins by bacteria. In Microorganisms and Nitrogen Sources, pp. 381-409. Edited by J. W. Payne. Chichester: John Wiley and Sons.

Law, B. A. \& Kolstad, J. (1983). Proteolytic systems in lactic acid bacteria. Antonie van Leeuwenhoek 49, 225-245.

Leblanc, D. J., Crow, V. L. \& LeE, L. N. (1980). Plasmid mediated carbohydrate catabolic enzymes among strains of Streptococcus lactis. In Plasmids and Transposons: Environmental Effects and
Maintenance Mechanisms, pp. 31-41. Edited by C. Stuttard \& K. R. Rozee. New York: Academic Press.

LEE, S. H. \& KIM, H. U. (1985). Studies on the antibiotic nisin produced by Streptococcus lactis IFO 12007. I. The production and purification of nisin. Korean Journal of Animal Science 27, 476-483.

Lindgren, S. E. \& DoBrogosz, W. J. (1990). Antagonistic activities of lactic acid bacteria in food and feed fermentations. FEMS Microbiology Reviews 87, 149-164.

LiU, W. \& Hansen, J. N. (1990). Some chemical and physical properties of nisin, a small protein antibiotic produced by Lactococcus lactis. Applied and Environmental Microbiology 56, 2551-2558.

Martin, J. F. \& Demain, A. L. (1980). Control of antibiotic biosynthesis. Microbiological Reviews 44, 230-251.

MarTin, J. F. \& LIRAS, P. (1989). Organization and expression of genes involved in the biosynthesis of antibiotics and other secondary metabolites. Annual Review of Microbiology 43, 173-206.

Oberman, H. \& JaCubowska, J. (1968). The formation of nisin in continuous cultivation of Streptococcus lactis 91. Chemia Spozywcza 100, 511-516.

Piard, J. C., Delorme, F. \& Desmazeaud, M. (1988). Characterization of the Streptococcus lactis bacteriocin lacticin DP1. In Abstract Book 8th International Biotechnology Symposium, Paris, July 17-22, 1988 , p. 223.

Rayman, K. N. \& HURST, A. (1984). Nisin: properties, biosynthesis and fermentation. In Biotechnology of Industrial Antibiotics, pp. 607-628. Edited by E. J. Vandamme. New York: Marcel Dekker.

SAHL, H.-G. \& Brandis, H. (1981). Production, purification and chemical properties of an antistaphylococcal agent produced by Staphylococcus epidermidis. Journal of General Microbiology 127, $377-384$.

Schagger, H. \& von Jagow, G. (1987). Tricine-sodium dodecyl sulphate polyacrylamide gel electrophoresis for the separation of proteins in the range from 1 to $100 \mathrm{kDa}$. Analytical Biochemistry 166, 368-379.

SCHILLINGER, U. \& LUCKE, F.-K. (1989). Antibacterial activity of Lactobacillus sake isolated from meat. Applied and Environmental Microbiology 55, 1901-1906.

Steele, J. L. \& McKay, L. L. (1986). Partial characterization of the genetic basis for sucrose metabolism and nisin production in Streptococcus lactis. Applied and Environmental Microbiology 51, $57-64$.

Steen, M. T., Chung, Y. J. \& Hansen, J. N. (1991). Characterization of the nisin gene as a part of a polycistronic operon in the chromosome of Lactococcus lactis ATCC 11454. Applied and Environmental Microbiology 57, 1181-1188.

TERZAGHI, B. E. \& SANDINE, W. E. (1975). Improved medium for lactic streptococci and their bacteriophages. Applied Microbiology 29, 807-813.

Thompson, J. (1988). Lactic acid bacteria: model systems for in vivo studies of sugar transport and metabolism in Gram-positive organisms. Biochimie 70, 325-336.

Tramer, J. \& Fowler, G. G. (1964). Estimation of nisin in foods. Journal of the Science of Food and Agriculture 15, 522-528.

TSAI, H. \& SANDINE, W. E. (1987). Conjugal transfer of nisin plasmid genes from Streptococcus lactis 7962 to Leuconostoc dextranicum 181. Applied and Environmental Microbiology 53, 352-357.

VANDAMme, E. J. (1981). Properties, biogenesis and fermentation of the cyclic decapeptide antibiotic gramicidin $\mathrm{S}$. In Topics in Enzyme and Fermentation Biotechnology, pp. 187-261. Edited by A. Wiseman. Chichester: Ellis Horwood.

VANDAMME, E. J. (1984). Biotechnology of Industrial Antibiotics. New York: Marcel Dekker. 